позиції філософії дослідження цього феномену відтворюють чітку картину поведінки, бажань і прагнень людини, iii стосунки 3 іншими людьми та довкіллям. Вивчення сугестивною лінгвістикою різних параметрів сугестивних текстів дозволяє створювати спеціальні тексти, які впливатимуть на установки особистості. У педагогіці застосування сугестії в процесі вивчення різних шкільних дисциплін уможливлює розкриття резервних можливостей особистості, сприяє покращенню психічного стану учнів, ефективному засвоєнню навчального матеріалу. У дослідженнях, присвячених професійній підготовці майбутніх учителів музики та фахівців факультетів мистецтв, пропонується використання сугестивних засобів задля стимулювання фантазії, формування образного мислення, створення атмосфери психологічного комфорту між викладачем і студентами та сприяє розвитку творчих здібностей особистості.

Подальша перспектива дослідження полягає у визначенні особливостей застосування сугестивних впливів майбутніми вчителями музики у професійній діяльності.

\title{
Література
}

1. Бехтерев В. М. Внушение и воспитание / В.М. Бехтерев // Объективное изучение личности: Избранные труды по психологии личности в 2-х томах. - Санкт-Петербург: Алетейя, 1999. - Т. 2. 283 с. 2. Даль В. И. Толковый словарь живого великоруського язика / В.И. Даль. - Т. 1: А-3. - 1989. 699 с. 3. Журавлев А.П. Звук и смисл : [кн. для внеклас. чтения учащихся ст. классов] / А.П. Журавлев. - 2-е изд., испр. и доп. - М. : Просвещение, 1991. - 160 с. 4. Козир А. В. Теорія та практика формування професійної майстерності вчителів музики в системі багаторівневої освіти : автореф. на здобуття наук. ступеня докт. пед. наук : 13.00.02, 13.00 .04 / А. В. Козир. - Київ, НПУ ім. М.П. Драгоманова, 2009. - 40 с. 5. Лозанов Г. К. Суггестология и суггестопедия - теория и практика / Г. К. Лозанов - София, 1971. 6. Пальчевський С. С. Сугестопедагогіка : новітні освітні технології : [навч. посібник] / С. С. Пальчевський. - К. : Кондор, 2005. - 351 с. 7. Симонов П. Сознание, подсознание, сверхсознание / П. Симонов // Наука и жизнь. - № 12. - 1975. - С. 45-51. 8. Федоришин В. Вплив сугестивних факторів на фахове становлення керівника оркестрового колективу / В. Федоришин // «Молодь і ринок». - № 2 (73), 2011. - С. 47-51. 9. Фрейд 3. Я и Оно / 3. Фрейд. - М. : МПО «МЕТТЭМ», 1990. - 56 с. 10. Черепанова И. Ю. Человек манипулирующий (суггестия в коммуникации) / И. Ю. Черепанова // Человек говорящий: язык, культура, познание: [межвузовский сборник научных трудов] / [ред. А. А. Романов, А. М. Шахнарович]. - Москва-Тверь: Институт языкознания РАН, Тверской Институт экономики и менеджмента, 1995. - С. 115-123. 11. Чубукова Т. Сугестія і сугестопедія у навчальному процесі / Т. Чубукова // Історія в школі, 1998. № 1. - С. 8-11. 12. Юнг К.-Г. Психология бессознательного / К.-Г. Юнг. - М., 1994. -249 с.

УДК 378.147.315.6:37.04

Володимир Онопа

\section{НЕТРАДИЦІЙНІ ПІДХОДИ ДО ОСМИСЛЕННЯ РЕГУЛЯТИВНОЇ ФУНКЦІї ПРИНЦИПУ ГРУНТОВНОСТІ ЗНАНЬ}

Онопа В. М. Нетрадиційні підходи до осмислення регулятивної функції принципу грунтовності знань.

У статті, у контексті аналізу регулятивної функції принципу грунтовності знань, розглядаються недостатньо вивчені положення, які стосуються засадничих гносеологічних умов досягнення грунтовного засвоєння людиною інформації. На грунті узагальнення досягнень сучасної сугестопедії визначаються загальні передумови моделювання психічних станів людини, подібних до натхнення; стимулювання уваги, повноцінного використання можливостей не лише усвідомлюваного напруженого зосередження, а й випадкових (зокрема периферичних) перцепцій.

Ключові слова: принципи дидактики, дидактичні умови грунтовного засвоєння знань, сугестопедія, моделювання психічних станів, інтуїція.

Онопа В. М. Нетрадиционные подходы к осмыслению регулятивной функции принципа основательности знаний.

В статье, в контексте анализа регулятивной функции принципа основательности знаний, рассматриваются недостаточно изученные положения, касающиеся основополагающих гносеологических условий достижения прочного усвоения человеком информации. На основании обобщения достижений современной суггестопедии определяются общие предпосылки 
моделирования психических состояний человека, подобных вдохновению; стимулирования внимания; полноценного использования возможностей не только осознаваемого напряженного сосредоточения, но и случайных (в т.ч. периферических) перцепций.

Ключевые слова: принципы дидактики, дидактические условия основательного усвоения знаний, суггестопедия, моделирования психических состояний, интуиция.

Onopa V. M. Unconventional approaches to understanding of regulative function of the principle of grounded knowledge.

The insufficiently studied positions concerning the fundamental gnoseological conditions of achievement of profound assimilation of information by a human are considered in the article in the context of analysis of the regulative function of the principle of grounded knowledge. On the basis of all the achievements of modern suggestopedia there are defined the general prerequisites of modeling of human mental states, such as inspiration, stimulation of attention, full use of opportunities not only of the conscious strained concentration, but also of the accidental (including peripheral) perceptions.

Key words: principles of didactics, didactic conditions of profound assimilation of knowledge, suggestopedia, modeling of mental states, intuition.

Аналіз спеціальної літератури і масової педагогічної практики не залишає сумнівів у тому, що грунтовність засвоєння навчального матеріалу була й залишається однією з важливих і складних наукових проблем.

Не вступаючи в полеміку щодо приналежності поняття «грунтовність знань» до того чи того розряду науково-педагогічних категорій, ми маємо констатувати той факт, що абсолютна більшість вітчизняних і зарубіжних науковців визнає його дидактичним принципом.

Необхідно підкреслити, що визначення сутності і змісту поняття «принцип дидактики» неодноразово ставало предметом дискусій і полемічних різнотлумачень. Однак, як справедливо зауважує, В. Краєвський, переважно обговорювалася сама категорія принципу, його філософська сутність. Специфіка ж реалізації акумульованих у принципах основоположних закономірностей, як таких, що відповідають за правильне функціонування педагогічної системи, у науковій теорії враховувалася далеко не завжди [1].

Повністю поділяючи думку науковця, ми вважаємо за необхідне наголосити на двох аспектах аналізованого питання. 3 одного боку, в загальнотеоретичному плані, принцип центральне поняття, покладене в основу сукупності фактів дійсності і є основоположною ідеєю, яка пронизує собою певну систему знань. У цьому розумінні принцип становить своєрідну логічну норму (орієнтир). 3 іншого боку, принцип розглядається як закон діалектичного руху i, таким чином, має розкривати особливості розвитку (дії).

Останнє не завжди береться до уваги при обгрунтуванні принципів навчання, що значною мірою нівелює випереджуючу функцію і соціальну значущість наукової теорії, покликаної вказувати шляхи перетворення і вдосконалення практики.

Мета статті - осмислення регулятивної функції принципу грунтовності знань в умовах запровадження інноваційних технологій навчання із застосуванням елементів сугестопедичних технологій.

Визначення регулятивної функції принципу грунтовності знань, яка повинна об'єднати в собі вказівки щодо організації навчально-пізнавальної діяльності і розкрити закономірності відповідного процесу, вимагає синтезу досягнень науки i результатів поглибленого цілеспрямованого вивчення масового педагогічного досвіду. Такий підхід дозволяє, по-перше, виявити і прослідкувати об'єктивно зумовлену необхідність дотримання вимог загальних законів пізнання людиною навколишньої дійсності (основоположні гносеологічні умови грунтовного засвоєння школярами навчального матеріалу); по-друге - розкрити особливості й найістотніші закономірності взаємодії динамічної сторони аналізованого принципу з дієвими компонентами інших педагогічних категорій (загальнопедагогічні умови); по-третє - визначити дидактичні умови практичного функціонування принципу грунтовності знань і досягнення передбачуваних його змістом результатів навчання.

Охарактеризувати належним чином зміст названих напрямків в одній статті неможливо, тому розглянемо лише окремі недостатньо вивчені (інколи суперечливі) положення, які стосуються загальних гносеологічних умов досягнення грунтовного засвоєння людиною інформації. 
Роботи вітчизняних і зарубіжних науковців, присвячені вивченню пізнавальної діяльності, глибоко розкривають взаємозв'язок мислення і мнемічних процесів, свідомості і пам'яті. При цьому інноваційні підходи до організації навчання й осмислення його закономірностей дозволяють деяким дослідникам висувати оригінальні припущення відносно природи сприймання, фіксації і довготривалого міцного запам'ятовування матеріалу, які відступають від загальноприйнятих і вже цим привертають до себе увагу.

Нині масових виявів сугестології нікого не дивує й відновлення інтересу до сугестивної педагогіки (сугестопедії). Ми переконані, що в повному обсязі (як автономна алгоритмізована технологія) остання має залишатися проблемою вузьких фахівців і не повинна мати широкого застосування. Однак дослідження науковців у цій галузі відкривають значно ширші, аніж за умов традиційного навчання, можливості вивчення психології і фізіології пізнавальної діяльності, що дозволяє зробити узагальнення, корисні для загальної педагогічної практики.

Головним дидактичним орієнтиром сугестопедагогіки $є$ забезпечення в умовах прискореного навчання міцного засвоєння навчального матеріалу. Це не викликає заперечень, оскільки досягнення високих якісних характеристик і довготривале утримання в пам'яті знань $\epsilon$ одним із головних критеріїв оцінки результативності навчального процесу за будь-яких умов. Щоправда, у першому випадку йдеться про гіпермнезію (надзапам'ятовування) і значне перевищення «звичайної» пам'яті. Запорукою успішного досягнення подібних результатів $\epsilon$ гіперкреативність - надпродуктивність навчальної праці, зумовлена, у свою чергу, над’якісною активізацією пізнавальних процесів (у тому числі уваги, інтуїції). Це дозволяє моделювати стани людини, подібні до натхнення.

Стосовно уваги, як невід'ємного інтегрального елемента активності, зазначимо, що стимулюється вона (про що свідчать результати багаторічних досліджень болгарських, російських, американських, австрійських, німецьких спеціалістів) збудженням не лише свідомих, але й парасвідомих функцій організму. Цим виправдовується доцільність такої організації навчального процесу, яка дозволяла б повноцінно використовувати можливості не лише усвідомлюваного напруженого зосередження, але й випадкових, особливо периферичних перцепцій.

Поняття «інтуїція», однаковою мірою $є$ цінним для наукового і навчального пізнання, досі глибоко не вивчене ні філософами (як форма гносеології), ні сугестологами чи парапсихологами. Словосполучення ж «активізація інтуїції» за первинного сприйняття викликає, щонайменше, здивування. Та вивчення цього складного явища паралельно 3 попереднім (увагою) показує, що в певних випадках воно виявляється в результаті впливу на психіку сильних подразників несподіваного характеру або зміни параметрів раніше діючих подразників, найчастіше пов'язаних із парадоксальністю, здивуванням тощо.

Безперечно, названі першопричини зовсім не обов'язково і не завжди є провісником інтуїтивних процесів, але майже повсякчас вони активізують мимовільну увагу, яка також виникає поза свідомими намірами. Отже, ми маємо певні підстави вважати мимовільну увагу якщо не умовою, то, принаймні супутником інтуїтивних передбачень i передчуттів, виникнення яких навряд чи можливе як наслідок вольових зусиль. Сказане ставить під сумнів правомірність переоцінки ролі в пізнанні притаманної людині довільної уваги, яку необхідно повноцінно використовувати як важливий етап на шляху переходу до уваги постдовільної (вторинно-мимовільної), здатної викликати захоплення, стимулювати творчу діяльність і, таким чином, підвищувати продуктивність процесу засвоєння знань.

Якщо те, про що ми вели мову вище, часом викликає певні сумніви чи просто видається не досить переконливим, то наступне положення сугестопедії - теорія про парасвідому основу довготривалої пам'яті - вступає у суперечність зі звичним твердженням психолого педагогічної науки, згідно з яким міцно і надовго запам'ятовуються, передовсім, результати активної свідомої інтелектуальної діяльності.

Стереотипи мислення й усталені переконання не дозволяють відразу зректися традиційних постулатів, але й наведений сугестологічний підхід не допускає безапелятивного заперечення, адже чим у такому разі можна пояснити, наприклад, миттєве запам'ятовування без найменших зусиль найрізноманітніших нісенітниць, незрозумілих звукосполучень-абракадабр, на зразок успішно використовуваних свого часу В. Шаталовим і його послідовниками сигнальних опор - абревіатур.

Однак наведені ілюстрації, які, безперечно, збуджують інтерес і змушують замислитися над багатьма речами, усе ж не позбавляють нас права на застереження від бездумного сприйняття на віру деяких позицій, відстоюваних окремими провідними дослідниками в царині сугестології. 
Вивчення фізіології діяльності і психологічних основ пізнання переконує в обов'язковому зниженні з часом продуктивності як фізичної, так і розумової праці, що зумовлене поступово зростаючою стомлюваністю організму. Втома негативно впливає на якість засвоєння навчального матеріалу і грунтовність засвоюваних знань. Поділяючи точку зору І. Павлова щодо наявності меж працездатності клітин кори головного мозку, ми вважаємо необхідною умовою їі відновлення чергування змінюваних видів діяльності з фазами відпочинку.

Підкреслимо, що йдеться про повноцінний відпочинок, а не «ефект відпочинку», який інколи створюється на окремих етапах навчально-виховного процесу.

Наведене положення не претендує на оригінальність, але різне його трактування на сторінках спеціальної літератури вимагає обгрунтування і доведення правомірності відповідної точки зору.

Роботи В. М'ясищева, Б. Паригіна, І. Шульца, Л. Рувінського, Д. Узнадзе, К. Платонова, С. Єлканова, В. Райкова доводять, що можливості людини невичерпні і за умов їх розкріпачення продуктивність пізнавальних процесів зростає в десятки разів, розкриваючи приховані до часу генетично закладені резерви пам'яті, інтелектуальної активності, креативності.

Важливим засобом пробудження потенціальних можливостей особистості названі та інші автори вважають навіювання і самонавіювання. Досягнуте подібним способом подолання внутрішніх психологічних упереджень в оцінці власного інтелектуального рівня і притаманного багатьом комплексу пізнавальної обмеженості за вмілої організації педагогічного процесу забезпечує досить грунтовне засвоєння особистістю результатів навчання.

Визначаючи наукову достовірність сказаного, ми все ж не можемо погодитися з деякими положеннями наукової теорії відомого болгарського сугестолога Г. Лозанова. Наприклад, 3 тим, що фази відпочинку тільки створюють передумови для зниження результативності навчального процесу, оскільки подібними паузами «вчитель підказує учневі», що він потребує відпочинку і розсіювання, тим самим актуалізуючи його внутрішню зорієнтованість на страх, змореність, незадоволення навчанням [2]. Повністю підтримуючи автора в тому, що «звеселяння як самоціль» у навчальному процесі не може бути виправданим, ми не відмовляємося від думки про необхідність педагогічно виправданих перерв для відпочинку.

Специфічне стимулювання навчально-пізнавальної діяльності i створення ефекту безперервної, як це видається при візуальному спостереженні, працездатності за допомогою спеціальних методик не виключає інтенсивного використання (аж до вичерпання) інтелектуальної енергії. Це так само очевидно, як і те, що в експерименті з підніманням тягарів піддослідними під гіпнотичним впливом створюється лише ілюзорна картина відсутності втоми від фізичної перенапруги. Уважаємо, що зухвало навіть припускати, що виконання м'язової роботи, у якому б то не було стані, можливе без адекватних затрат енергії (поглинання енергоємкості організму).

Якщо в останньому випадку, не маючи необхідних наукових даних, ми можемо здогадно говорити лише про наявність невідчутних до часу фізичних перевантажень, то в попередньому, який цікавить нас значно більше, йдеться про складніші і серйозніші речі.

Надмірна інтенсифікація мисленнєвих і мнемічних процесів за свідомої відмови від фаз відновлення рано чи пізно призведе до психоневрологічного виснаження організму, наслідки якого можуть виявитися через роки як найнепередбачуваніші патології. Чи не це мав на увазі філософ і психотерапевт Тодор Дичев, навівши в одній із наукових дискусій приклади психічних, гормональних, імунологічних відхилень, які в тяжких формах почали виявлятися в учасників Лозанівських експериментів з інтенсивного вивчення іноземної мови протягом наступних п'яти років після їх успішного, як здавалося спершу, завершення [3].

Здійснивши стислий огляд окремих нетрадиційних спроб осмислення регулятивної функції принципу грунтовності знань, зауважимо, що питання потребує подальшого вивчення, але майбутнє, на нашу думку, за технологіями, що передбачають поєднання переваг класичних і нових (нестандартних) підходів до розв'язання проблеми.

\section{Література}

1. Краевский В. В. Проблемы научного обоснования обучения / Володар Викторович Краевский. М. : Педагогика, 1977. - 264 с. 2. Лозанов Г. Суггестология й суггестопедия - теория й практика / Георгий Лозанов. - София, 1978. - 68 с. 3. Перевозчиков А. Н. Феномен? Синдром? Или... / Александр Николаевич Перевозчиков // Знание : Новое в жизни, науке, технике. Сер. «Знак вопроса». 1990. - №6. - C. 36-39. 